УДК 37.016:811(477.82)

DOI: $\underline{10.35619 / \text { iiu.v2i13.331 }}$

Триндюк Валентина

кандидат педагогічних наук, викладач циклової комісії словесних дисциплін

Комунального закладу вищої освіти «Луцький педагогічний коледж»

Волинської обласної ради,

м. Луцьк, Україна

ORCID: 0000-0002-8326-3740

e-mail: tryndiuk_va@ukr.net

Мартинюк Алла

кандидат педагогічних наук, доцент кафедри іноземної та української філології Луцького національного технічного університету, м. Луцьк, Україна

ORCID: 0000-0002-5979-3936 e-mail:alla-mart@ukr.net

Губіна Алла

кандидат психологічних наук, доцент кафедри іноземної та української філології Луцького національного технічного університету,

м. Луцьк, Україна

ORCID: 0000-0002-8966-9581

e-mail: hubinaalla@ukr.net

\title{
ОСОБЛИВОСТІ ОРГАНІЗАЦІЇ ЗАНЯТЬ 3 ІНОЗЕМНОЇ МОВИ В УМОВАХ ЗМІШАНОГО НАВЧАННЯ
}

Анотація. У статті проаналізовано змішане навчання (blended learning) та форми його організації. Blended learning розглядається як модель освітнього процесу із чітким комбінуванням очної та онлайн-форм навчання із використанням технічних засобів та Інтернет-ресурсів. 3'ясовано, що планування ефективної моделі змішаного навчання 3 іноземної мови - це сукупність взаємопов'язаних видів навчальної діяльності, де вагоме місце займає самостійна робота студента й цілеспрямована робота викладача.

Наголошується на тому, що роль викладача у змішаному навчанні модифікується і зводиться до ролі творця, модератора, контролера. Викладач у змішаному навчанні - розробник Робочої програми 3 дисципліни/Силабусу, керівник і виконавець свого «проєкту». Змішане навчання переважно зосереджене на готовності викладача, який мотивує студентів до вивчення мови, добре володіє технічними можливостями використання навчальних платформ у режимі онлайн, чітко визначає

(C) Триндюк В., Мартинюк А., Губіна А., 2021 


\section{Інноватика у вихованні. Випуск 13.Том 2. 2021.}

доцільність певного виду завдання із своєї дисципліни, розуміє основну мету кожного завдання, яке готує студента до оволодіння кінцевими компетентностями та відповідає змісту освітньої програми.

Правильно організована самостійна робота студента $є$ ефективною у процесі формування усіх видів мовленнєвої діяльності - читання, говоріння, аудіювання та письмо. Завдання 3 іноземної мови та їх види відіграють вагому роль і впливають на якість отриманих знань. Дієвим предиктором успішної комунікації іноземною мовою в умовах змішаного навчання, на думку авторів, стане організація самостійної роботи студентів, яка трансформується у виконання студентами чітко складених некомунікативних та умовно-комунікативних вправ. У статті окреслено різноманітні види завдань для організації самостійної роботи з іноземної мови в умовах змішаного навчання.

Ключові слова: змішане навчання, онлайн-освіта, формат навчання, іноземна мова, самостійна робота, види вправ, платформа, роль вчителя.

Постановка проблеми. Освітянська спільнота України сьогодні знаходиться у складних умовах, коли необхідно досить мобільно реагувати на виклики пандемії та швидко пристосовуватись до викладання в умовах, що склалися. Науковцям усього світу стали звичними такі терміни, як дистанційна освіта, онлайн-освіта, змішане навчання. Використовувати традиційне навчання подекуди стало неможливо та неактуально. Впровадження нових технологій у освітній процес значною мірою полегшило роботу викладачів у сучасних реаліях та дало можливість вдосконалювати організацію навчання, ефективно змінювати підходи і перейти на сучасніший, якісніший рівень викладання. Науковці за кордоном активно впроваджують змішане навчання (blended learning). Не залишаються осторонь від його імплементації у освітній процес і наші вітчизняні вчені. Зокрема, було опубліковано узагальнені «Рекомендації щодо впровадження змішаного навчання у закладах фахової передвищої та вищої освіти» (далі Рекомендації) (МОН України, 2020).

Необхідність впровадження змішаного навчання у викладанні іноземної мови в ЗВО зумовлює перегляд підходів до подачі матеріалу студентам, до безпосереднього пояснення нових тем для формування основних видів мовленнєвої діяльності: письма, читання, говоріння та аудіювання.

Для застосування на заняттях іноземної мови на сьогодні $є$ безліч доступних у всесвітній мережі платформ, які дають можливість вдосконалити освітній процес 3 дисципліни та перейти до нового якісного викладання. Однак немає єдиної оптимальної та ефективної моделі, яка б застосовувалась для вивчення іноземної мови. Пошук нових технологій, платформ та курсів у мережі Інтернет в умовах змішаного навчання $\epsilon$ актуальною та необхідною темою для розгляду задля подальшого їхнього використання в освітньому процесі. 


\section{Інноватика у вихованні. Випуск 13.Том 2. 2021.}

Аналіз останніх досліджень 3 проблеми. Змішане навчання як форма організації навчального процесу активно досліджується сьогодні у працях зарубіжних науковців (Allen I., Barrett B., Christensen C., Horn M., and Staker H., Bonk C., Dziuban C., Garrett R., Garrison R., Kanuka H., Kmnar S., Picciano A., Sharma P., Shea P., Siddiqi A., White J.) та українських учених (Є. В. Бутенкова, Л. В.Десятова, М. Г. Свдокимова, Ю. І. Капустіна, О. В. Львова, М. Н. Мохова, А. Л. Назаренко, М. А. Татаринова, С. В. Титова). Вивченню використання освітньої моделі blended learning у процесі опанування певних дисциплін присвячені праці О. М. Спіріна, Ю. В. Триуса, В. М. Кухаренка, А. М. Стрюка.

Переваги і недоліки змішаної форми навчання для вивчення іноземної мови у ЗВО проаналізовані О. Щербаковою та Ж. Ніколаєвою (2017, с. 71). В. Баркасі та С. Баркасі (2015) розглянули шляхи підвищення рівня знань іноземної мови студентів вищих навчальних закладів у разі застосування змішаної форми навчання та пропонують використання певних платформ. Н. Тимощук (2019) презентує власний електронний курс «English for Technologists», який застосовується в процесі змішаного навчання. Ставлення студентів до змішаного навчання на заняттях 3 іноземної мови (англійської) досліджували О. Безлюдний, В. Безлюдна, I. Щербань, О. Комар (2019). Однак на тепер ще мало доробок 3 конкретних практичних порад щодо видів діяльності та різновиду вправ на заняттях іноземної мови в умовах змішаного навчання.

Мета статті - проаналізувати теоретичні та практичні рекомендації щодо оптимальних підходів в організації змішаного навчання, його методичної та технологічної складової; з'ясувати, які види діяльності та різновиди вправ для самостійної роботи використовуються на заняттях іноземної мови у процесі змішаного навчання.

Виклад основного матеріалу дослідження. Змішане навчання освітня концепція, що дозволяє використовувати традиційні та інноваційні методи навчання. Студент відвідує «живі» заняття в аудиторії, але при цьому широко застосовує у своєму навчанні інформаційно-комунікаційні технології (IКT) через пристрої обробки інформації: персональний комп'ютер, електронний записник, мобільні пристрої тощо (Безлюдний та iн., 2019).

Іноземні науковці називають змішане навчання «гібридним» нововведенням, яке $є$ спробою забезпечити «найкраще 3 обох світів» тобто поєднати переваги онлайн-навчання 3 усіма перевагами традиційного класу (Christensen, Horn \& Staker, 2013, с. 4).

Ми підтримуємо думку Щербакової О. та Ніколаєвої Ж. (2017), які трактують змішане навчання (blended learning) як форму організації викладання, яка передбачає дуалістичне поєднання очної та дистанційної форм роботи, не зменшуючи роль викладача у навчальному процесі, не надаючи їй другорядності, радше він перестає бути транслятором знань, а стає координатором, що організовує спільну діяльність студентів та спонукає їх до самостійної діяльності. 


\section{Інноватика у вихованні. Випуск 13.Том 2. 2021.}

y blended learning - комбінованій моделі навчання - основою для студентів $\epsilon$ онлайн-навчання як противага традиційним заняттям в аудиторії. Роль учителя трансформується у фасилітатора (модератора, інформатора, помічника), а студент виконує роль «водія», для якого така модель відкриває новий рівень гнучкості щодо місця, способу, темпу та часу навчання. Отже, blended learning $\epsilon$ ідеальним середовищем для розгортання систем на основі компетентнісного підходу, які також виключають суворо обмежене в часі навчання. Фактично, використовуються гнучкі моделі змішаного навчання як-от Flex, Individual Rotation, Enriched Virtual, A La Carte, де час безпосереднього перебування на занятті (в аудиторії) не $\epsilon$ визначальним показником ефективності навчання (White, 2019).

Загалом змішане навчання передбачає повне чи часткове відвідування занять, дистанційне, онлайн-навчання та поєднання обох форм (рис. 1 (Панасюк, 2020).

Насамперед хочемо наголосити, що blended learning у закладах освіти впливає на зміст освітніх програм і потребує перегляду видів діяльності. На заняттях 3 іноземної мови в умовах змішаного навчання ми використовуємо різноманітні форми роботи зі студентами, комбінуємо платформи 3 відеоуроками, спеціалізованими програмами для дистанційного та онлайн-навчання. Викладання іноземної мови відбувається із застосуванням технічних засобів, які стали невід'ємною частиною діяльності усіх учасників освітнього процесу.

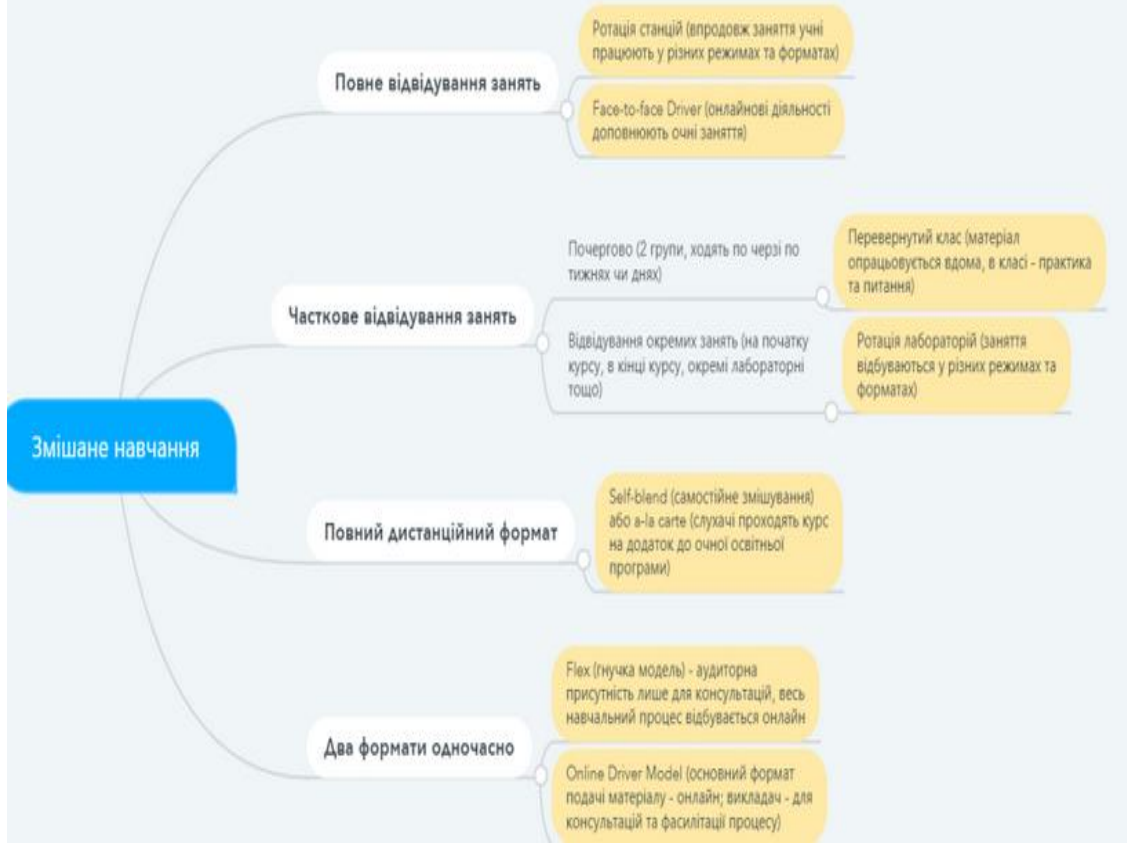

Рис. 1. Форми та види діяльності в умовах змішаного навчання 


\section{Інноватика у вихованні. Випуск 13.Том 2. 2021.}

Предметом наших досліджень було також питання можливостей електронних ресурсів на занятті з іноземної мови (Губіна та Мартинюк, 2019), де ми описували використання сервісу GOOGLE CLASSROOM у процесі опанування студентами іноземної мови у немовному ЗВО. Однак, виклики сьогодення спонукають нас до постійних пошуків удосконалення технологій, форм та видів діяльності у викладанні іноземних мов.

Першочерговим завданням викладача у змішаному навчанні $\epsilon$ методичне проєктування власної дисципліни як послідовності дій та досвіду, що його здобувач отримає впродовж курсу. Науковці пропонують підходити до планування усього процесу вивчення дисципліни як до сукупності взаємопов'язаних видів навчальної діяльності студентів. Відповідно до сучасних Рекомендацій (МОН України, 2020), впровадження змішаного навчання у закладах освіти - це «деталізована підготовка й організація не лише аудиторних занять, а насамперед самостійної роботи студентів». Безумовно, таке твердження $є$ слушним, оскільки самостійна робота у форматі blended learning стає ключовою у всіх видах i формах роботи зі студентами (зважаючи на повний, чи частковий дистанційний формат; очний, чи змішаний формат).

Аналізуючи моделі змішаного навчання (Station Rotation, Lab Rotation, Individual Rotation, Flipped Classroom, Self-blend aбо A la carte, Flex, Online-Driver-Model (White, 2019; Панасюк, 2020), було з'ясовано, що вони передбачають чітко організовану самостійну роботу студента. А роль викладача, як згадано вище, модифікується і зводиться до ролі творця, модератора, контролера. Викладач у змішаному навчанні розробник Робочої програми 3 дисципліни/Силабусу, керівник i виконавець свого «проєкту». Завдання викладача - це, здебільшого, спонукання до обговорення попередньо самостійно опрацьованого студентами матеріалу, перевірка вивченого, коригування індивідуальних знань та навичок окремої групи чи студента, оцінювання знань тощо.

Відповідно до Рекомендацій (МОН України, 2020), ми намагаємося скоректувати традиційні методи навчання на заняттях іноземної мови у сучасні інтегровані високотехнологічні онлайн-зустрічі. Щодо видів діяльності, то підходимо до цього питання комбіновано, використовуючи поряд з аудиторними заняттями face-to-face-зустрічі у Zoom, Google Meet та Viber для організації дистанційної роботи студентів. Вважаємо, що використання цих онлайн-застосунків $\epsilon$ доволі зручним, простим, доступним на усіх технічних засобах та $\epsilon$ достатньо вивченим як викладачами, так і студентами.

Відповідно до етапів формування навичок та вмінь мовлення на занятті іноземної мови використовуються різні види вправ. Типи та види вправ класифікуються за двома критеріями: 1) спрямованість на прийом або видачу інформації (рецептивні, репродуктивні, рецептивнорепродуктивні, продуктивні та рецептивно-продуктивні); 2) комунікативність (некомунікативні, умовно-комунікативні, комунікативні) (Скляренко, 1992, с. 9-14). Отже, некомунікативні та 


\section{Інноватика у вихованні. Випуск 13.Том 2. 2021.}

умовно-комунікативні вправи застосовуються на початковому етапі для формування навичок, а комунікативні вправи на наступних етапах для формування вмінь.

Вважаємо, що аудиторні види діяльності або онлайн face-to-faceзустрічі в умовах змішаного навчання $\epsilon$ досить продуктивними та корисними для розвитку навичок говоріння та письма, формування комунікативних умінь іноземною мовою. Такі заняття спрямовані на виконання комунікативних вправ (рецептивно-продуктивні мовленнєві вправи). Щодо письма зауважимо, що правильність виконання письмового завдання потребує попереднього узгодження усіх вимог до написання різних видів текстів (есе, листів, повідомлень, звітів і т.д.), тренування необхідних мовних кліше, аналізу зразків завдань тощо, де «живе» пояснення викладача буде необхідним.

Дієвим предиктором успішної комунікації іноземною мовою в умовах blended learning, на нашу думку, стане організація самостійної роботи студентів, яка трансформується у виконання студентами чітко складених комунікативних та умовно-комунікативних вправ (рецептивні, репродуктивні, рецептивно-репродуктивні вправи) із використанням технічних засобів та онлайн-ресурсу. Іншими словами - це виконання вправ, спрямованих на прослуховування або читання навчального матеріалу, що передбачають повне або часткове відтворення прослуханого/прочитаного.

Зауважимо, що підготовка завдань для самостійної роботи з іноземної мови потребує ретельної підготовки, креативних та ефективних нових підходів викладача. Виконання таких завдань повинно мотивувати студентів до комунікації іноземною мовою.

Презентуємо практичні напрацювання різноманітних видів завдань для організації самостійної роботи з іноземної мови в умовах змішаного навчання:

опрацювати словниковий мінімум за допомогою онлайн-словників, після чого переглянути відео із запропонованими словами за посиланням;

переглянути відеоматеріали 3 онлайн-ресурсу та відповісти на запитання до тексту, надіслані викладачем, виконати тести до тексту;

відтворити читання тексту за диктором;

послухати діалог та записати переказ у минулому часі;

опрацювати граматичні правила та виконати тестові завдання, надіслані викладачем, або у Google-формі; вправи на закріплення теми за посиланням;

виписати транскрипцію поданих слів, записати відеозапис із читанням лексики та синонімів до кожного слова іноземною мовою;

прочитати текст та надіслати аудіозапис виписаних антонімів до підкреслених слів;

підготувати відеозапис власних роздумів студента на задану тему; прочитати текст та надіслати відеозапис короткого переказу тексту; 


\section{Інноватика у вихованні. Випуск 13.Том 2. 2021.}

Для впровадження в освітній процес поданих завдань ми використовуємо онлайн-ресурси 3 вивчення англійської мови, а саме: British Council Learn English, BBC Learning English, навчальну платформу Udemy, онлайн-словники (Multitran, Merriam-Webster, Cambridge dictionary та ін.), You Tube, курси англійської мови Gateway, New Destinations, Mission.

Упродовж відтворення діалогів та текстів, студенти не лише вдосконалюють фонетичні вміння, а й завчають до автоматизму лексику, фразеологізми, граматичні конструкції, здатні швидко поставити запитання/відповісти на запитання. Така організація самостійної роботи досить ефективна у процесі підготовки студентів до досягнення достатнього рівня комунікативної компетентності. Самостійно виконані завдання стають основою для практичного відтворення вивченого матеріалу у письмових роботах, усних розповідях, використанні мовних кліше у діалогах/обговореннях тощо.

Запропоновані види завдань мають переваги як для студентів, так i для викладачів. Насамперед для студентів, визнаних «центром» освітнього процесу, завдання $є$ доступні на усіх сучасних гаджетах, $\epsilon$ можливість працювати із оригінальними автентичними матеріалами, немає обмеження у часі для виконання, $є$ можливість перезапису власної відповіді при наявності помилок та ін. Викладачі, створивши такі завдання, суттєво скорочують час для перевірки (наприклад, прослуховування або перегляд студентських робіт заощаджує час викладача; Google Classroom дає можливість отримати одразу результати тестів; коригування помилок викладачем за такі види завдань можуть відбуватися із використанням звукових повідомлень окремим студентам або для групи).

Висновки і перспективи подальших розвідок. Blended learning - це сучасна модель освітнього процесу із чітким комбінуванням аудиторної та онлайн-форм навчання 3 використанням технічних засобів та Інтернетресурсів.

Змішане навчання здебільшого зосереджене на готовності викладача до такого виду діяльності. Зокрема, він повинен добре володіти технічними можливостями використання навчальних платформ у режимі онлайн, налагодити face-to-face-зустрічі зі студентами, мотивувати студентів до вивчення мови, чітко визначати доцільність певного виду завдання зі своєї дисципліни, розуміти основну мету кожного завдання, яке готує студента до оволодіння кінцевими компетентностями та відповідає змісту освітньої програми; контролювати час, вміти швидко провести оцінювання.

Імплементація онлайн-ресурсів у навчальні Програми 3 іноземної мови повинна бути належно продумана, усі види завдань мають відповідати темі заняття, рівню знань студентів, а кожне дистанційне чи онлайн завдання вимагає методичного обгрунтування доцільності застосування та відповідності формування ключових компетентностей 3 іноземної мови. 
Планування ефективної моделі змішаного навчання ми розуміємо як сукупність взаємопов'язаних видів навчальної діяльності, де вагоме місце займає самостійна робота студента й цілеспрямована робота викладача.

Завдання 3 іноземної мови для самостійної роботи та їх види ефективно впливають на розвиток усіх навичок мовленнєвої діяльності і відіграють вагому роль у формуванні комунікативних вмінь майбутніх фахівців в цілому.

Структурування видів завдань для самостійної та аудиторної роботи на заняттях $з$ іноземної мови в умовах змішаного навчання можуть бути предметом подальших досліджень.

\section{СПИСОК ВИКОРИСТАНИХ ДЖЕРЕЛ}

Міністерство освіти і науки України, (2020). Рекомендації щзодо впровадження змішаного навчання у закладах фахової передвищої та вищої освіти. 58 с. URL: https://mon.gov.ua/storage/app/media/vishchaosvita/2020/zmyshene\%20navchanny/zmishanenavchannia-bookletspreads2.pdf. [Дата звернення 14.01.21].

Щербакова, О., Ніколаєва, Ж. (2017). Змішане навчання як форма організації навчального процесу з іноземної мови у ВНЗ. Молодий вчений. № 4. CC. 69-73.

Баркасі, В., Баркасі, С. (2015). Використання змішаної форми навчання при викладанні іноземних мов у ВНЗ. «Young Scientist». № 2 (17). c. 201-206. http://molodyvcheny.in.ua/files/journal/2015/2/339.pdf. [Дата звернення 14.01. 21].

Тимощук, Н. (2019). Застосування моделі blended learning під час викладання іноземної мови в немовному (аграрному) ЗВО. Педагогіка формування творчої особистості у вищій $i$ загальноосвітній школах. № 62, T. 2. CC. 216-220. URL: http://pedagogy-journal.kpu. zp.ua / archive/2019/62/part_2/45.pdf. [Дата звернення 15.01.21].

Безлюдний, О., В. Безлюдна, В., Щербань, І., Комар, О. (2019). Досвід використання змішаного навчання на заняттях з англійської мови у закладах вищої педагогічної освіти. ISSN: 2076-8184. В: Інформачійні технології $i$ засоби навчання. Том 73, No 5. CC.86-100. URL: https://www.researchgate.net/publication/336951520_dosvid_vikoristanna_zmi sanogo_navcanna_na_zanattah_z_anglijskoi_movi_u_zakladah_visoi_pedagogi cnoi_osviti. [Дата звернення 14.01.21].

Christensen, C., Horn, M., and Staker, H. (2013). Is K-12 Blended Learning Disruptive? An introduction to the theory of hybrids. May, 2013. P.4. URL: https://www.christenseninstitute.org/wp-content/uploads/2014/06/Is-K12-blended-learning-disruptive.pdf. [Дата звернення 15.01.21].

White, J. (2019). For mastery-based approaches, consider a disruptive blended-learning model, September 4, 2019. URL: https://www.blendedlearning.org/for-mastery-based-approaches-consider-adisruptive-blended-learning-model/. [Дата звернення 15.01.21]. 


\section{Інноватика у вихованні. Випуск 13.Том 2. 2021.}

Панасюк, О. (2020). Моделі змішаного навчання. Wordpress. 05.10.2020. URL: https://oksanapasichnyk.wordpress.com/2020/10/05/blendedpractice/._Дата звернення 15.01.21].

Губіна, А., Мартинюк, А. (2019). Можливості сервісу google classroom у навчанні іноземної мови у ЗВО. В: Наукові записки Національного університету "Острозька академія». серія «Філологія», Острог: Вид-во НаУОА. Вип. 5 (73). СС.184-187.

Скляренко, Н. (1992). Типологія вправ в інтенсивному навчанні іноземних мов. В: Гуманітарні аспекти лінгвістичних досліджень $i$ методики викладання іноземних мов : Збірник наукових праць. К.: КДППМ. с. 9-14.

\section{REFERENCES}

Ministerstvo osvity i nauky Ukrainy, (2020). Rekomendatsii shchodo vprovadzhennia zmishanoho navchannia u zakladakh fakhovoi peredvyshchoi ta vyshchoi osvity [Recommendations for introduction of blended learning in the higher vocational in pre higher educational institutions]. 58 c. URL: https://mon.gov.ua/storage/app/media/vishcha-osvita/2020/zmyshene $\% 20$ navchanny/zmishanenavchannia-bookletspreads-2.pdf. [Data zvernennia 14.01.21]. [in Ukrainian].

Shcherbakova, O., Nikolaieva, Zh. (2017). Zmishane navchannia yak forma orhanizatsii navchalnoho protsesu $\mathrm{z}$ inozemnoi movy u VNZ. [Blended learning as a form of organizing the learning process of teatching a foreign language in in the university]. Molodyi vchenyi. No 4. SS. 69-73. [in Ukrainian].

Barkasi, V., Barkasi, S. (2015). Vykorystannia zmishanoi formy navchannia pry vykladanni inozemnykh mov u VNZ. [Blended learning usage in teaching foreign languages in the universities]. Molodyi uchenyi. No 2 (17). s. 201-206. http://molodyvcheny.in.ua/files/ journal/2015/2/339.pdf. [Data zvernennia 14.01.21]. [in Ukrainian].

Tymoshchuk, N. (2019). Zastosuvannia modeli blended learning pid chas vykladannia inozemnoi movy v nemovnomu (ahrarnomu) ZVO. [Introducing the Blended Learning model for teaching foreign language at nonlinguistic (agrarian) institutions of higher education]. V: Pedahohika formuvannia tvorchoi osobystosti $u$ vyshchii $i$ zahalnoosvitnii shkolakh. No 62, T.2. CC.216220. URL: http://pedagogy-journal.kpu.zp.ua/archive/2019/62/part_2/45.pdf [Data zvernennia 15.01.21]. [in Ukrainian].

Bezliudnyi, O., Bezliudna V., Shcherban I., Komar O. (2019). Dosvid vykorystannia zmishanoho navchannia na zaniattiakh $\mathrm{z}$ anhliiskoi movy $\mathrm{u}$ zakladakh vyshchoi pedahohichnoi osvity. [Experience of blended learning using at english lessons in pedagogical higher education institutions]. ISSN: 2076-8184. V: Informatsiini tekhnolohii i zasoby navchannia. Tom 73, No 5. S.86-100. URL: https://www.researchgate.net/publication/336951520_ dosvid _vikoristanna_zmisanogo_navcanna_na_zanattah_z_anglijskoi_movi_u_zaklad ah_visoi_pedagogicnoi_osviti. [Data zvernennia 14.01.21]. [in Ukrainian]. 


\section{Інноватика у вихованні. Випуск 13.Том 2. 2021.}

Christensen, C., Horn, M., and Staker, H. (2013). Is K-12 Blended Learning Disruptive? An introduction to the theory of hybrids. May, 2013. P.4. URL: https://www.christenseninstitute.org/wp-content/uploads /2014 /06/Is-K12-blended-learning-disruptive.pdf. [Data zvernennia 15.01.21]. [in English].

White, J. (2019). For mastery-based approaches, consider a disruptive blended-learning model, September 4, 2019. URL: https://www.blendedlearning.org/for-mastery-based-approaches-consider-adisruptive-blended-learning-model/. [Data zvernennia 15.02.21].

Panasiuk, O. (2020). Modeli zmishanoho navchannia. [Blended learning models]. Wordpress. 05.10.2020. URL: https://oksanapasichnyk. wordpress.com/2020/10/05/blended-practice/. [Data zvernennia 15.01.21]. [in Ukrainian].

Hubina, A., Martyniuk, A. (2019). Mozhlyvosti servisu google classroom u navchanni inozemnoi movy u zvo. [Google classroom service in teaching a foreign language at universities]. V: Naukovi zapysky Natsionalnoho universytetu "Ostrozka akademiia". seriia "Filolohiia", Ostroh: Vyd-vo NaUOA. Vyp. 5(73). St.184-187. [in Ukrainian].

Skliarenko, N. (1992). Typolohiia vprav v intensyvnomu navchanni inozemnykh mov. [Typology of exercises in intensive foreign language teatching]. V: Humanitarni aspekty linhvistychnykh doslidzhen $i$ metodyky vykladannia inozemnykh mov: Zbirnyk naukovykh prats. K.: KDPPM. SS.9-14. [in Ukrainian].

\section{PECULIARITIES FOR ORGANIZING FOREIGN LANGUAGE CLASSES USING BLENDED LEARNING}

Valentyna Tryndiuk

Candidate of Pedagogical Sciences, teacher at the cycle commission of philological disciplines

Municipal Institution of Higher Education "Lutsk Pedagogical College" of Volyn Regional Council,

Lutsk, Ukraine

ORCID: 0000-0002-8326-3740

e-mail: tryndiuk_va@ukr.net

Alla Martyniuk

Candidate of Pedagogical Sciences, Associate Professor at the Department of Foreign and Ukrainian Philology Lutsk National Technical University, Lutsk, Ukraine

ORCID: 0000-0002-5979-3936 e-mail:alla-mart@ukr.net

Alla Hubina

Candidate of Psychological Sciences, Associate Professor at the Department of Foreign and Ukrainian Philology Lutsk National Technical University, Lutsk, Ukraine 
ORCID: 0000-0002-8966-9581

e-mail: hubinaalla@ukr.net

Abstract. The article analyzes blended learning and forms of its organization. Blended learning is seen as a model of the educational process with a clear combination of face-to-face and online forms of learning using technical means and online resources. It was found that the planning of an effective model of blended learning in a foreign language is a set of interrelated types of educational activities, where the independent work of the student and the purposeful work of the teacher play an important role.

It is emphasized that the role of the teacher in blended learning is transformed and reduced to the role of a creator, moderator, controller. The teacher in blended learning is the developer of the Discipline Work Program/Syllabus, the leader and executor of his/her "project". Blended learning is mainly focused on the readiness of the teacher, who motivates students to learn the language, has a good technical ability to use learning platforms online, clearly defines the feasibility of a particular task in its discipline, understands the main purpose of each task and corresponds to the content of the educational program.

Properly organized independent work of the student is effective in the process of forming all types of speech activity: reading, speaking, listening and writing. Tasks in a foreign language and their types play an important role and affect the quality of knowledge. An effective predictor of successful communication in a foreign language in a blended learning environment will be the organization of students' independent work, which is transformed into the performance by students of clearly composed non-communicative and conditionally communicative exercises. The article outlines various types of tasks for organizing independent work on a foreign language in a blended learning environment.

Keywords: blended learning, online education, learning format, foreign language, independent work, types of exercises, platform, teacher's role.

Стаття надійшла до редакиії 16. 02. 2021p. 